\title{
VIEWS OF HEALTH CARE PERSONNEL ON ORGAN DONATION AND TRANSPLANTATION: A LITERATURE REVIEW
}

\author{
Francisco Javier Mercado-Martínez"1, César Padilla-Altamira², Blanca Díaz-Medina³, Carlos Sánchez- \\ Pimienta ${ }^{4}$
}

\footnotetext{
${ }^{1}$ Ph.D. Departamento de Salud Pública, Universidad de Guadalajara. Guadalajara, México. E-mail: fjaviermercado@yahoo.com.mx ${ }^{2}$ M.Sc. Department of Public Health and Policy, University of Liverpool. Liverpool, United Kingdom. E-mail: c.padilla-altamira@ liverpool.ac.uk

${ }^{3}$ Psic. Centro Universitario de Ciencias de la Salud, Universidad de Guadalajara, Guadalajara, México. E-mail:alex_eminem@hotmail. com

${ }^{4}$ Centro Universitario de Ciencias de la Salud, Universidad de Guadalajara. Guadalajara, México. E-mail: carlos.cesp@gmail.com
}

\begin{abstract}
The purpose of this study was to review the empirical studies on health personnel's views towards organ donation and transplantation. A scoping review was carried out in English, Portuguese and Spanish. The search was conducted in eight databases, and two search engines. Four groups of descriptors were used. The period covered was 1985 to 2013 . Frequency and content analysis was performed. Two hundred forty-eight articles were selected, out of 316 identified. The literature is temporally and geographically clustered. Quantitative studies predominate. The studies prioritized the perspective of medical and nursing personnel over other actors, such as directors and organ donation coordinators. Health personnel's attitudes toward deceased organ donation was the most examined topic. In conclusion, a growing quantitative literature analyzes the perspective of physicians and nurses with regard to deceased organ donation and transplantation.
\end{abstract}

DESCRIPTORS: Organ donation. Organ transplantation. Health personnel. Attitudes. Review.

\section{A VISÃO DO PESSOAL DE SAÚDE SOBRE A DOAÇÃO E TRANSPLANTE DE ÓRGÃOS: REVISÃO DE LITERATURA}

RESUMO: O propósito do estudo foi revisar os artigos empíricos sobre a visão do profissional de saúde em relação à doação e transplante de órgãos. Uma revisão panorâmica da literatura foi realizada em espanhol, inglês e português; e a busca desenvolvida em oito bases de dados e dois motores de busca. O período analisado foi de 1985 a 2013. Análises de frequências e conteúdo foram desenvolvidas. Dos 316 trabalhos identificados, 248 foram selecionados. A produção concentra-se em termos espaciais e temporais, predominando aqueles trabalhos com metodologias quantitativas. As publicações priorizaram a perspectiva dos médicos e profissionais da enfermagem sobre outros atores, como os diretores. As atitudes dos profissionais de saúde sobre a doação de órgãos de falecido foi o tópico mais estudado. Conclui-se que um número cada vez maior de estudos quantitativos analisa a perspectiva dos médicos e profissionais de enfermagem sobre a doação e transplante de órgãos de falecidos.

DESCRITORES: Doação de órgãos. Transplante de órgãos. Pessoal de saúde. Atitudes. Revisão.

\section{LA VISIÓN DEL PERSONAL DE SALUD SOBRE LA DONACIÓN Y EL TRASPLANTE DE ÓRGANOS: UNA REVISIÓN DE LA LITERATURA}

\begin{abstract}
RESUMEN: El objetivo de este estudio fue revisar los estudios empíricos sobre la visión del personal de salud respecto a la donación y trasplante de órganos. Se hizo una revisión panorámica de la literatura en español, inglés y portugués; realizándose la búsqueda en dos buscadores y ocho bases de datos. El periodo abarca de 1985 al 2013. Se hizo análisis de contenido y frecuencias. De 316 artículos identificados, 248 fueron seleccionados. Según los hallazgos, los trabajos se concentraron en términos temporales y espaciales; predominando aquellos con metodologías cuantitativas. Las publicaciones priorizaron la perspectiva del personal médico y enfermería sobre las de otros actores, como directivos y coordinadores de donación. Las actitudes del personal sanitario hacia la donación de órganos de fallecido fue el tema más estudiado. Se concluye que una producción creciente de tipo cuantitativo analiza la perspectiva de médicos y enfermeras sobre la donación y trasplante de órganos de fallecido.
\end{abstract}

DESCRIPTORES: Donación de órganos. Trasplante de órganos. Personal de salud. Actitudes. Revisión. 


\section{INTRODUCTION}

Organ transplantation has been considered one of the most significant advances in modern medicine. ${ }^{1}$ Around the world, countless organ donation and procurement initiatives have been promoted and have also been key elements in strengthening a growing number of transplant programs. However, a variety of factors have made the supply and availability of organs lag behind the demand, ${ }^{2}$ resulting in an increase in the number of people waiting for a transplant. ${ }^{3}$

During the last few decades, not only has there been much progress on the biomedical front, but much literature has been published about different stakeholders with important roles in the organ and tissue donation and/or transplant process. The focus of most studies - whether singly or jointly - is usually on donors, recipients, families, health care personnel, the media or the public at large. ${ }^{4-6}$

Health care personnel have been considered a key factor for the success or failure of transplant programs. ${ }^{7}$ Their views and opinions on the donation process, for example, have facilitated the identification of potential donors and thus are highly influential in the way people think about the process. ${ }^{8-10}$ Although empirical studies on health care personnel's point of view have been conducted, few studies have reviewed the literature as a whole. ${ }^{11}$ Some reviews have compared the knowledge and attitudes of nurses toward organ donation across countries; ${ }^{9}$ others have synthesized the literature on the attitudes of these professionals towards brain death and organ donation; ${ }^{8}$ some others have reviewed research on attitudes of medical personnel toward organ donation in the case of cardiac death. ${ }^{12}$ In spite of this progress, to date there has been no encompassing overview of the work on health care professionals' perspectives on the organ donation and transplant processes; in particular, no account has been taken of publications in languages other than English. The latter is important because non-English speaking countries, such as Spain, Portugal and Brazil, have made significant advances in organ donation and transplantation and in publishing their experience. ${ }^{13}$

The aim of this study was to review the empirical literature on the views held by health care personnel on organ donation and transplantation. In the context of this paper we use the terms "view," "point of view" and "perspective" synonymously. What these terms have in common is that they refer to how individuals encounter and evaluate social reality, acknowledging that these concepts have their own characteristics and are used differently according to the theoretical perspective adopted.

\section{METHODS}

We carried out a scoping review of the literature. Following Arksey \& $\mathrm{O}^{\prime}$ Malley, ${ }^{14}$ we aimed to map relevant literature on the perspectives of health care personnel on organ donation and transplantation. Unlike other reviews that start from a definite question, here we did not consider a relevant initial question, because our interest was in addressing a broader issue and including studies with different designs and methodologies.

We used two search engines - PubMed and Google Scholar - and eight data bases - ProQuest, EBSCO, SAGE Journals Online, ScienceDirect, Wiley Online Library, Periodicals Archive Online, SciELO and Redalyc - to identify and retrieve relevant studies. We used four groups of keywords in English, Portuguese and Spanish: a) health care personnel, nurses, doctors, surgeons, donation coordinators, organ procurement and transplant coordinators, social worker, transplant physicians and nephrologists; b) procurement, donation, organ transplantation; c) attitudes, perceptions, perspectives, beliefs, representations, experiences and meanings; d) qualitative, ethnography, survey.

The literature was selected using these criteria: empirical studies published in indexed journals, whose aim was to study the views of health care personnel on organ donation and transplantation; health care personnel as the primary data source; and papers published in Spanish, English or Portuguese. We excluded studies on tissue transplants and on health care personnel's practices. The period covered was from 1985 to 2013, and the search process was concluded in March, 2014. The operational definition of the term "views of health care personnel" in this review arose from the terms used in the $\mathrm{MeSH}$, as well as from the studies identified in our searches, which refer to what individuals encounter in their respective social realities and their interaction with other social agents. On this basis, studies that used concepts such as knowledge, attitudes, beliefs, opinions, insights, experiences and meanings were 
also included. The term "donation coordinators" was used to refer any of the numerous persons responsible for the organ procurement process. Transplant coordinators, hospital coordinators, and donation and transplant coordinators are some terms used in the literature.

Once the studies were identified and selected, they were reviewed and summarized in a matrix. We conducted content analysis, ${ }^{15}$ which consisted in identifying the main categories, subtopics and study population. A frequency analysis was carried out using the software PASW 18. When studies included more than one type of health care professional or examined several issues, they were classified in all the relevant categories. As a result, some cells have numbers exceeding $100 \%$. Figure 1 shows the procedure used to identify and select the papers.

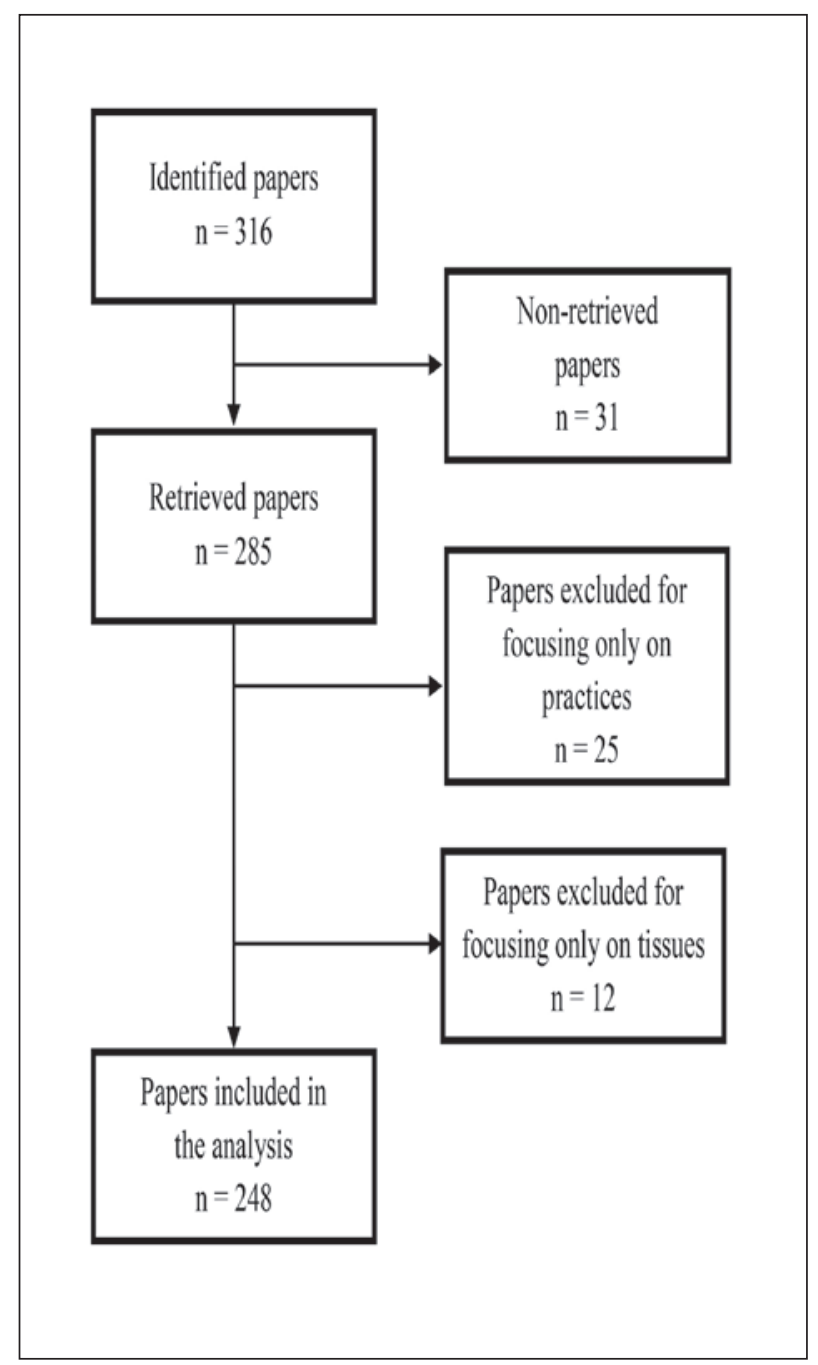

Figure 1 - Paper selection procedure

\section{RESULTS}

A total of 316 papers were identified, of which 248 were selected. As seen in Table 1, the number of papers increased over the years. The first three $(1.2 \%)$ appeared in the second half of the $1980 \mathrm{~s}$, increasing to $39(15.7 \%)$ in the period from 2000 to 2004 and to 106 (42.3\%) from 2010 to 2013. This increasing trend is observed in all regions, but studies from North America are distributed throughout the period, while Africa is represented only in the last decade.

The studies were conducted in 44 countries, but significantly clustered by regions and countries. The largest number of papers came out of European countries (37.1\%) followed by North America (28.7\%). Together these represent almost two thirds of the total $(65.9 \%)$, and were followed far behind by Asian countries (15.3\%), while less than $10 \%$ of the research came from Latin America and the Caribbean, Oceania and Africa together. Almost two-thirds of the studies $(62.5 \%)$ were carried out in six countries: United States $(22.8 \%)$, Spain (16.9\%), Australia (6.4\%), Canada (6.0\%), Brazil (5.6\%) and the UK (4.8\%).

The studies were mainly in English (89.1\%), although there were also some in Spanish $(8.9 \%)$ and Portuguese $(2.0 \%)$. The number of publications increased over time in all languages, although there are papers in English throughout the period, while papers in Spanish appeared only from the 1990s onward.

Most of the studies (73.9\%) used quantitative methodologies, but from 2000 onward, a significant number of qualitative studies $(22.9 \%)$ began to appear, and in the last five years, some papers $(3.2 \%)$ which used mixed methodologies were published. Qualitative studies have gained importance over the years: whereas there were none in the first five-year period analyzed, they represented $11.1 \%$ in the period $1990-1994$, and subsequently they made up more than $20 \%$ in all the later five-year periods. Methodologies also differed by country; quantitative studies predominate in Spain and the US $(97.7 \%$ and $69.6 \%$, respectively), while the majority of papers were qualitative in Brazil (64.2\%), Sweden $(60.0 \%)$ and Canada $(53.3 \%)$, and a large proportion of UK studies $(41.6 \%)$ used mixed methods. 


\section{Table 1 - Characteristics of the studies by five-year periods}

\begin{tabular}{|c|c|c|c|c|c|c|}
\hline \multirow{2}{*}{ Variables } & \multicolumn{6}{|c|}{ Five-year periods } \\
\hline & 1985-1989 & 1990-1994 & 1995-1999 & 2000-2004 & 2005-2009 & $2010-2013$ \\
\hline Studies $(n=248)$ & $3(1.2)$ & $9(3.6)$ & $25(10.1)$ & $39(15.7)$ & $67(27.0)$ & $105(42.4)$ \\
\hline \multicolumn{7}{|l|}{ World regions } \\
\hline Europe $(n=92)$ & - & $1(1.1)$ & $6(6.5)$ & $10(10.9)$ & $35(38.0)$ & 40 (43.5) \\
\hline North America $(\mathrm{n}=71)$ & $3(4.2)$ & $7(9.8)$ & $11(15.4)$ & $10(14.0)$ & $17(23.9)$ & $23(32.7)$ \\
\hline Asia $(n=38)$ & - & - & $4(10.5)$ & $10(26.3)$ & $8(21.1)$ & $16(42.1)$ \\
\hline Latin America $(\mathrm{n}=24)$ & - & $1(4.2)$ & $2(8.3)$ & $6(25.0)$ & $5(20.8)$ & $10(41.7)$ \\
\hline Oceania $(n=18)$ & - & - & $2(11.1)$ & $3(16.6)$ & $1(5.5)$ & $12(66.8)$ \\
\hline Africa $(n=5)$ & - & - & - & - & $1(20.0)$ & $4(80.0)$ \\
\hline \multicolumn{7}{|l|}{ Publication language } \\
\hline English $(n=221)$ & $3(1.3)$ & $7(3.1)$ & $23(10.4)$ & 34 (15.3) & $58(26.2)$ & $96(43.7)$ \\
\hline Spanish $(n=22)$ & - & $1(4.5)$ & $2(9.0)$ & $4(18.1)$ & $9(41.2)$ & $6(27.2)$ \\
\hline Portuguese $(n=5)$ & - & $1(20.0)$ & $0(0.0)$ & $1(20.0)$ & - & $3(60.0)$ \\
\hline \multicolumn{7}{|l|}{ Study type } \\
\hline Quantitative ( $\mathrm{n}=183$ ) & $3(1.6)$ & $8(4.3)$ & $18(9.8)$ & $30(16.3)$ & $48(26.2)$ & $76(41.8)$ \\
\hline Qualitative $(\mathrm{n}=57)$ & - & $1(1.7)$ & $6(10.5)$ & $9(15.7)$ & $18(31.5)$ & $23(40.6)$ \\
\hline Mixed methods $(n=8)$ & - & - & $1(12.5)$ & - & $1(12.5)$ & $6(75.0)$ \\
\hline \multicolumn{7}{|l|}{ Composition of the samples } \\
\hline Physicians $(n=168)$ & $3(1.7)$ & $2(1.1)$ & 17 (10.1) & $26(15.4)$ & $42(25.0)$ & $78(46.7)$ \\
\hline Nurses (n=151) & $2(1.3)$ & $6(3.9)$ & $17(11.2)$ & $28(18.5)$ & $41(27.1)$ & $57(38.0)$ \\
\hline Others $(n=44)$ & - & $1(2.2)$ & $2(4.5)$ & $7(15.9)$ & $13(29.5)$ & $21(47.9)$ \\
\hline Donation Coordinators $(\mathrm{n}=39)$ & - & $0(0.0)$ & $4(10.2)$ & $6(15.3)$ & $13(33.3)$ & $16(41.2)$ \\
\hline Health Managers $(n=15)$ & $1(6.6)$ & $0(0.0)$ & $1(6.6)$ & - & $3(20.0)$ & $10(66.8)$ \\
\hline \multicolumn{7}{|l|}{ Examined concepts } \\
\hline Attitudes ( $\mathrm{n}=157)$ & $3(1.9)$ & $6(3.8)$ & $18(11.4)$ & 27 (17.2) & $47(29.9)$ & $56(35.8)$ \\
\hline Knowledge (n=83) & $2(2.4)$ & $5(6.0)$ & $12(14.4)$ & $21(25.3)$ & $14(16.8)$ & $29(35.1)$ \\
\hline Perceptions $(n=57)$ & - & $1(1.7)$ & $5(8.7)$ & $5(8.7)$ & $16(28.0)$ & $30(52.9)$ \\
\hline Opinions $(n=41)$ & - & $3(7.3)$ & $2(4.8)$ & $4(9.7)$ & $5(12.2)$ & $27(66.0)$ \\
\hline Experiences $(n=23)$ & - & - & - & $5(21.7)$ & $7(30.4)$ & $11(47.9)$ \\
\hline Meanings $(n=17)$ & - & $1(5.8)$ & $2(11.7)$ & $4(23.5)$ & $7(41.4)$ & $3(17.6)$ \\
\hline \multicolumn{7}{|l|}{ Topics } \\
\hline Organ donation $(n=214)$ & $3(1.4)$ & $8(3.7)$ & $23(10.7)$ & 37 (17.2) & $64(29.9)$ & $79(37.1)$ \\
\hline Deceased donor $(n=158)$ & $3(1.9)$ & $8(5.0)$ & $21(13.2)$ & $36(22.7)$ & $43(27.2)$ & $47(30.0)$ \\
\hline Living donor $(\mathrm{n}=33)$ & - & - & $2(6.0)$ & - & $19(57.7)$ & $12(36.3)$ \\
\hline Donation in general terms $(n=23)$ & - & - & - & $1(4.3)$ & $2(8.7)$ & $20(87.0)$ \\
\hline Brain death $(n=70)$ & $2(2.8)$ & $1(1.4)$ & $10(14.2)$ & $19(27.1)$ & $14(20.0)$ & $24(34.5)$ \\
\hline Organ transplantation $(n=69)$ & - & $3(4.3)$ & $6(8.7)$ & $12(17.3)$ & $8(11.5)$ & $40(58.2)$ \\
\hline Donation in general terms $(n=37)$ & - & - & $2(5.4)$ & $4(10.8)$ & $3(8.1)$ & $28(75.7)$ \\
\hline Deceased donor $(n=23)$ & - & $3(13.0)$ & $2(8.7)$ & $8(34.8)$ & $2(8.7)$ & $8(34.8)$ \\
\hline Living donor $(n=9)$ & - & - & $2(22.2)$ & - & $3(33.3)$ & $4(44.5)$ \\
\hline
\end{tabular}

In some studies, the health care personnel studied were selected by profession, whereas in other studies, by job profile. Most of the studies focused on the perspective of physicians and nursing staff $(67.7 \%$ and $60.8 \%$, respectively). Only $15.7 \%$ of the papers were concerned with the views of donation coordinators and even fewer $(6.0 \%)$ with the perspective of health managers and decisionmakers. Another $17.7 \%$ examined the viewpoints of other health care workers (e.g, psychologists, social workers, nutritionists, ambulance drivers).
Again, the distribution of focus varied over time; that is, studies on doctors and nurses were found throughout the period, while interest in other health care personnel was concentrated in the last three five-year periods.

No single concept was used to examine the viewpoints of health care personnel, but rather a variety of conceptual tools, as seen in table 1. Nearly two-thirds of the studies $(63.3 \%)$ focused on health care workers' attitudes towards donation and transplantation, while one-third (33.4\%) 
examined their knowledge. Significantly fewer studies $(22.9 \%)$ chose to analyze their perceptions, $16.5 \%$ their opinions, $9.2 \%$ their experiences and $6.8 \%$ their meanings. Studies of attitudes, knowledge and opinions of health care personnel were distributed throughout the review period, while those on perceptions, experiences and meanings were concentrated in the more recent periods.

The topic that was the focus of the most attention $(86.2 \%)$ was the health care workers' view of organ donation, and to a lesser extent their perspective on brain death $(28.2 \%)$ and on transplants $(27.8 \%)$. The majority of the 214 papers on health care workers' views on organ donation $(73.9 \%)$ examined their views on cadaveric donation, while living organ donation was the subject of only $15.4 \%$ of the papers, and $10.7 \%$ were about organ donation in general. The distribution was different in the 69 papers that studied their perspective on transplants: most studies (53.7\%) did not distinguish between cadaveric and living donation, one third $(33.3 \%)$ focused on cadaveric donation and only $13.0 \%$ on living donation.

Analyzing these issues in greater detail over the entire period shows that interest in cadaveric donation and transplantation and in brain dead donors increased significantly from the 1980s onward. Interest in living donation and transplantation from living donors emerged in the second half of the 1990s.

The papers were not distributed in the same way with respect to health care personnel and the concepts used. As shown in table 2, the papers that studied physicians, nurses and other professionals examined their attitudes and knowledge, whereas the majority (51.2\%) of studies on donation and/or transplant coordinators focused on their perceptions. In contrast, although fewer in number $(n=15)$ the studies on health managers and decision-makers were interested in their attitudes as well as in their perceptions, opinions, experiences and knowledge.

Table 2 - Distribution of the studies by health personnel type and studied concepts

\begin{tabular}{lcccccc}
\hline & \multicolumn{6}{c}{ Studied concepts } \\
\cline { 2 - 6 } Health Personnel & $\begin{array}{c}\text { Attitudes } \\
\mathbf{n}(\%)\end{array}$ & $\begin{array}{c}\text { Knowledge } \\
\mathbf{n}(\%)\end{array}$ & $\begin{array}{c}\text { Opinions } \\
\mathbf{n}(\%)\end{array}$ & $\begin{array}{c}\text { Perceptions } \\
\mathbf{n}(\%)\end{array}$ & $\begin{array}{c}\text { Experiences } \\
\mathbf{n}(\%)\end{array}$ & $\begin{array}{c}\text { Meanings } \\
\mathbf{n}(\%)\end{array}$ \\
\hline Physicians $(\mathrm{n}=168)$ & $111(66.0)$ & $56(33.3)$ & $39(23.2)$ & $31(18.4)$ & $7(4.7)$ & $8(4.7)$ \\
Nurses $(\mathrm{n}=151)$ & $102(67.55)$ & $55(36.4)$ & $20(13.2)$ & $31(20.5)$ & $14(9.2)$ & $10(6.6)$ \\
Other Health Personnel $(\mathrm{n}=44)$ & $32(72.7)$ & $16(36.3)$ & $7(15.9)$ & $6(13.6)$ & $2(4.5)$ & $2(4.5)$ \\
Donation Coordinators $(\mathrm{n}=39)$ & $9(23.0)$ & $5(12.8)$ & $6(15.3)$ & $20(51.2)$ & $5(12.80)$ & $8(20.5)$ \\
Health Managers $(\mathrm{n}=15)$ & $6(40.0)$ & $3(20.0)$ & $4(26.6)$ & $5(33.3)$ & $3(20.0)$ & $1(6.6)$ \\
\hline
\end{tabular}

Table 3 shows a different facet of the selected studies. Here components of the organ donation and transplantation process are examined according to health professions and job profile. As can be seen, most studies on doctors, nurses and other professionals have prioritized their viewpoints on organ donation. In contrast, studies of donation coordinators and health care managers and decision makers examined both organ donation and transplantation.

Table 3 - Distribution of studies by health personnel type and topics

\begin{tabular}{lccc}
\hline & \multicolumn{3}{c}{ Studied topics } \\
\cline { 2 - 4 } Health personnel & Organ donation & Organ transplantation & Brain death \\
& $\mathbf{n}(\%)$ & $\mathbf{n}(\%)$ & $\mathbf{n}(\%)$ \\
\hline Physicians $(\mathrm{n}=168)$ & $140(83.3)$ & $54(32.1)$ & $44(26.1)$ \\
Nurses $(\mathrm{n}=151)$ & $135(89.4)$ & $35(23.1)$ & $49(32.4)$ \\
Donation coordinators $(\mathrm{n}=39)$ & $30(76.9)$ & $17(43.5)$ & $8(20.5)$ \\
Other health personnel $(\mathrm{n}=44)$ & $37(84.0)$ & $15(34.0)$ & $11(25.0)$ \\
Health managers $(\mathrm{n}=15)$ & $8(53.3)$ & $8(53.3)$ & $2(13.3)$ \\
\hline
\end{tabular}


The attitudes of health care personnel towards organ donation was the specific topic studied by the majority of papers $(59.2 \%)$. The papers examined one or more of three interrelated topics: attitudes towards organ donation in general, towards donating one's own organs, and towards donation of a family member's organs. Table 4 shows studies carried out in 26 countries; three particular findings can be noted. First, the percentage of health care professionals with a positive attitude towards organ donation in gen- eral tends to be higher than those with a positive attitude toward donation of their own organs or those of their relatives. Second, the percentage of doctors with a positive attitude toward donation tends to be higher than that of other health care professionals. Third, the percentage of health care professionals with a positive attitude towards donation and transplantation tends to be higher in Europe and North America than in other regions of the world.

Table 4 - Favorable attitudes (\%) from health personnel to organ donation in general terms (A), donation of their own organs (B), and donation of their family member's organs (C) according to studies from 26 countries

\begin{tabular}{|c|c|c|c|c|c|c|}
\hline \multirow{2}{*}{ Author(s) } & \multirow{2}{*}{ Year } & \multirow{2}{*}{ Country } & \multirow{2}{*}{$\mathrm{HP} †$} & \multicolumn{3}{|c|}{ Favorable attitudes* } \\
\hline & & & & A & B & $\mathrm{C}$ \\
\hline Mazaris, et al. ${ }^{16}$ & 2011 & UK & $\mathrm{HP}$ & 98 & 94 & -- \\
\hline Erdoğan, et al. ${ }^{17}$ & 2002 & Turkey & PHY & 98 & -- & 61 \\
\hline Chernenko, et al. ${ }^{18}$ & 2005 & Canada & $\mathrm{HP}$ & 98 & -- & -- \\
\hline Evanisko, et al. ${ }^{19}$ & 1998 & USA & PHY & 96 & 80 & 85 \\
\hline Bøgh, Madsen ${ }^{20}$ & 2005 & Denmark & PHY & 95 & 70 & -- \\
\hline Nowikowska, et al. ${ }^{21}$ & 2003 & Poland & $\mathrm{HP}$ & 94 & 85 & 53 \\
\hline Abidin, et al. ${ }^{22}$ & 2013 & Malaysia & $\mathrm{HP}$ & 93 & 47 & -- \\
\hline Weber, Canbay ${ }^{23}$ & 1999 & Germany & PHY & 91 & 84 & -- \\
\hline Duke, et al. ${ }^{24}$ & 1998 & Australia & NURß & 91 & 72 & 57 \\
\hline Pugliese, et al. ${ }^{25}$ & 2001 & Italy & HP & 89 & 77 & -- \\
\hline Ríos, et al. ${ }^{26}$ & 2012 & Spain & $\mathrm{HP}$ & 86 & -- & -- \\
\hline Yuet-mui, et al. ${ }^{27}$ & 1997 & China & NUR & 85 & 40 & -- \\
\hline Alsaied, et al. ${ }^{28}$ & 2012 & Qatar & $\mathrm{HP}$ & 83 & 21 & 25 \\
\hline Shabanzadeh, et al. ${ }^{29}$ & 2009 & Iran & NUR & 76 & -- & 54 \\
\hline Kim, et al. ${ }^{30}$ & 2006 & Korea & NUR & 68 & 39 & 25 \\
\hline Siddiqui, et al. ${ }^{31}$ & 2012 & Pakistan & $\mathrm{HP}$ & 51 & 35 & 36 \\
\hline Smudla, et al. ${ }^{32}$ & 2013 & Hungary & $\mathrm{HP}$ & -- & 95 & -- \\
\hline Leal-Mateos, et al. ${ }^{33}$ & 2005 & Costa Rica & $\mathrm{HP}$ & -- & 94 & -- \\
\hline Abudd-Filho, et al. ${ }^{34}$ & 1997 & Brazil & $\mathrm{HP}$ & -- & 93 & 80 \\
\hline Omnell-Persson et al. ${ }^{35}$ & 1998 & Estonia & PHY & -- & 78 & 50 \\
\hline Gorena et al. ${ }^{36}$ & 2006 & Chile & NUR & -- & 75 & 55 \\
\hline Omnell-Persson, et al ${ }^{35}$ & 1998 & Lithuania & PHY & -- & 69 & 50 \\
\hline Rodríguez, Monteon ${ }^{37}$ & 2004 & Mexico & $\mathrm{HP}$ & -- & 64 & -- \\
\hline Reddy, et al. ${ }^{38}$ & 2003 & India & PHY & -- & 62 & -- \\
\hline Omnell-Persson, et al. ${ }^{35}$ & 1998 & Latvia & PHY & -- & 55 & 30 \\
\hline Al-Mousawi, et al. ${ }^{39}$ & 2001 & Kuwait & NUR & -- & 53 & 33 \\
\hline
\end{tabular}

* Sorted in descending order from column A; † Health Personnel; † Physicians; § Nurses.

\section{DISCUSSION}

We reviewed 248 empirical studies conducted in 44 countries. The main contribution of this review is to present an overview of research published in three languages on the viewpoints of health care personnel on organ donation and transplantation. Other authors have published reviews on this subject, but these generally exam- ine a part of the whole picture and are limited to publications in English. ${ }^{8}$ If the present study had reviewed only papers in English, $12 \%$ of the total would had been excluded; that is, those reporting research in Spain and Brazil. More papers were found in Spanish than in Portuguese. A plausible explanation of such finding is that there is a lack of interest in Brazilian academia in studying what 
health care personnel think and do with respect to organ donation and transplantation, on the assumption that there is universal free access to health care in Brazil, including renal therapy. ${ }^{40}$

Although nearly fifty countries were represented, they do not give a full worldwide picture of the viewpoints of health care personnel, nor throughout the study period. This is because the studies examined are temporally and geographically clustered. That is, the studies reviewed represent research published during the last twenty-five years, but particularly since 2000. In fact, it seems that interest in knowing what health care personnel think about this issue did not emerge until the early 1990s, which coincides with the growing shortage of cadaveric organs and the consolidation of transplant programs in various countries around the world. ${ }^{41}$ Moreover, if almost two-thirds of the work was conducted in two regions of the world, and a similar figure in six countries, the information obtained enables understanding what health care personnel in European and North American countries think about organ donation and transplantation. However, the same can not be said of other regions or countries, given that there is little information on the topic. For example, in spite of advances in organ donation and transplantation in Latin America and the Caribbean, studies on the subject from this region are virtually nonexistent, except for Brazil.

The research reported here use predominantly quantitative methodologies. This hegemony is not only of interest for the use of specific designs and strategies for collecting and analyzing data, but also because it relates to the same objects of study. In other words, the employment of this approach is useful to examine topics that are subject to measurement and quantification, including their causal factors. Attitudes, knowledge and opinions of health care personnel thus became prime objects of attention. The former was the concept that received the most attention and predominated in the field. Attitude is a concept commonly used by social psychologists, and refers to a relatively consistent tendency of individuals to respond to someone or something in such a way as to reflect their positive or negative evaluation of that person or thing. ${ }^{42}$ For this reason, most of the research in this field draws on contributions of American social psychology, based on neopositivist perspectives. ${ }^{43}$

Advances in qualitative and mixed methods have been quite promising in this field of research.
This represents a paradigm shift toward a focus on people. ${ }^{44}$ That is, the growing number of these studies is evidence of an increasing interest in the subjective, experiential, and symbolic dimensions of health. Studies on perceptions, meanings and experiences are a part of this trend. The results of some of these studies show another facet of the problem by revealing, for example, that the donation and transplantation process is emotionally demanding and generates stress and conflicts among health care personnel. ${ }^{45}$ These studies draw on interpretivist approaches, particularly phenomenology and symbolic interactionism, and to a lesser extent on critical theory and participatory research. In fact, interest in qualitative methodologies in this field seems to be a reflection of new trends in health care research in general or in specific topics such as in chronic disease. ${ }^{46}$

The attitudes of health personnel toward cadaveric donation was the single specific topic that received the most attention in the reviewed studies. Interest in this subject could be explained by the fact that the countries where the majority of studies were carried out share an interest in organ donation and transplantation from deceased donors. These include the United States, Spain, Australia, Brazil and Canada. ${ }^{13}$ However, health care workers' perceptions and actions towards living donation have been little explored. Among other issues remaining to investigate in the future would be that of perceptions, experiences and practices of health care personnel in countries that have prioritized living over cadaveric donation. Case studies in Jordan, Turkey, Lebanon and Mexico could serve to shed more light on the matter, as these are countries where this type of donation is promoted. ${ }^{47}$

The perspective of physicians and nurses have been privileged in the reviewed papers, in contrast to the scarce interest shown in what other health care professionals involved in the process think. According to our findings, physicians and nurses have a positive attitude towards donation and transplantation in general, but their attitude is less positive when it comes to donating their own organs or those of their family members. The studies also show that the percentage of doctors with a positive attitude is usually higher than that of nurses, and the percentage is generally higher in European and North American countries than in Asia, Latin America or the Caribbean. Despite these findings, more comparative studies are required, both among regions and within countries. 
For example, it would be relevant to compare the viewpoints of health care personnel employed by private and public systems within the same country. It would also be important to include in these studies other key actors involved in the process, such as managers, decision-makers and donation coordinators. ${ }^{48}$

\section{FINAL CONSIDERATIONS}

This review provides information at the worldwide level on the viewpoints of health care personnel about organ donation and transplantation. In this study, we have documented a strong and growing research output that, using quantitative methodologies, has prioritized the attitudes of physicians and nurses toward cadaveric organ donation and transplantation. But the review also shows gaps and challenges in this area; among these is the dearth of information existing on the perspective of health care personnel from various regions and countries on the issue. Nor have the viewpoints of all stakeholders been represented. In addition to advances, one challenge is to consolidate the qualitative research in this field, and to incorporate ethnographic, participatory and critical approaches. Understanding the findings of this study may serve to suggest and promote new topics for research and redefine the role of health care personnel in this field.

\section{ACKNOWLEDGMENTS}

The authors want to thank Margaret Schroeder for translating this paper.

\section{REFERENCES}

1. Linden PK. History of solid organ transplantation and organ donation. Crit Care Clin. 2009 Jan; 25(1):165-84.

2. The Transplantation Society of Latin America and the Caribbean. Latin American Transplantation. Report 2009. Duro-Garcia V, Santiago-Delpin EA, Pestana JOM, editors. San Juan: The Latin American and Caribbean Transplant Society; 2010.

3. Childress JF, Liverman CT, editors. Organ donation. Opportunities for action. Washington: National Academies Press; 2006.

4. Matesanz R, editor. El modelo español de coordinación y trasplantes. 2nd ed. Madrid (ES): Aula Médica; 2008.

5. Bousso RS. O processo de decisão familiar na doação de órgãos do filho: uma teoria substantiva. Texto Context Enferm. 2008; 17(1):45-54.
6. Mendes KDS, Roza B de A, Barbosa S de FF, Schirmer J, Galvão CM. Transplante de órgãos e tecidos: responsabilidades do enfermeiro. Texto Context Enferm. 2012; 21(4):945-53.

7. Shafer TJ, Wagner D, Chessare J, Zampiello FA, McBride V, Perdue J. Organ donation breakthrough collaborative: increasing organ donation through system redesign. Crit Care Nurse. 2006 Apr; 26(2):33$42,44-8$

8. DuBois JM, Anderson EE. Attitudes toward death criteria and organ donation among healthcare personnel and the general public. Prog Transplant. 2006 Mar; 16(1):65-73.

9. Collins TJ. Organ and tissue donation: a survey of nurse's knowledge and educational needs in an adult ITU. Intensive Crit Care Nurs. 2005 Aug; 21(4):226-33.

10. Kim JR, Elliott D, Hyde C. The influence of sociocultural factors on organ donation and transplantation in Korea: findings from key informant interviews. J Transcult Nurs. 2004 Apr; 15(2):147-54.

11. Mercado-Martínez FJ, Padilla-Altamira C, DíazMedina BA. La donación y el trasplante de órganos segun los profesionales de la salud. Panorama bibliográfico y bibliografía anotada. Guadalajara (MX): Universidad de Guadalajara; 2010.

12. Bastami S, Matthes $\mathrm{O}$, Krones T, Biller-Andorno N. Systematic review of attitudes toward donation after cardiac death among healthcare providers and the general public. Crit Care Med. 2013 Mar; 41(3):897-905.

13. Global Observatory on Donation and Transplantation. Organ donation and transplantation activities 2012. [online]. ONT, WHO, editors. 2014 [cited 2014 Apr 8]. Retrieved from: http://www.transplantobservatory.org/Pages/Data-Reports.aspx

14. Arksey H, O'Malley L. Scoping studies: towards a methodological framework. Int J Soc Res Methodol. 2005 Feb; 8(1):19-32.

15. Hsieh H-F, Shannon SE. Three approaches to qualitative content analysis. Qual Health Res. 2005 Nov; 15(9):1277-88.

16. Mazaris EM, Crane JS, Warrens AN, Smith G, Tekkis P, Papalois VE. Attitudes toward live donor kidney transplantation and its commercialization. Clin Transplant. 2011; 25(3):E312-9.

17. Erdoğan O, Yücetin L, Tuncer M, Keçecioğlu N, Gürkan A, Akaydin M, et al. Attitudes and knowledge of Turkish physicians about organ donation and transplantation. Transplant Proc. 2002 Sep; 34(6):2007-8.

18. Chernenko SM, Jensen L, Newburn-Cook C, Bigam DL. Organ donation and transplantation: a survey of critical care health professionals in nontransplant hospitals. Prog Transplant. 2005 Mar; 15(1):69-77. 
Mercado-Martínez FJ, Padilla-Altamira C, Díaz-Medina B, Sánchez-Pimienta C

19. Evanisko MJ, Beasley CL, Brigham LE, Capossela C, Cosgrove GR, Light J, et al. Readiness of critical care physicians and nurses to handle requests for organ donation. Am J Crit Care. 1998 Jan; 7(1):4-12.

20. Bøgh L, Madsen M. Attitudes, knowledge, and proficiency in relation to organ donation: A questionnaire-based analysis in donor hospitals in northern Denmark. Transplant Proc. 2005 Oct; 37(8):3256-7.

21. Nowikowska A, Smietanski M, Pirski M, Sledzinski Z. Hospital attitude survey. Implementing a Donor Action programme in hospitals of Pomerania region, northern Poland. Organs and Tissues. 2003; 6(3):161-6.

22. Abidin ZLZ, Ming WT, Loch A, Hilmi I, Hautmann O. Are health professionals responsible for the shortage of organs from deceased donors in Malaysia? Transpl Int. 2013 Feb; 26(2):187-94.

23. Weber F, Canbay AE. Attitudes of physicians and nursing staff members toward organ donation in an urban area of Germany. Transplant Proc. 1999 Aug; 31(5):2179-80.

24. Duke J, Murphy B, Bell A. Nurses' attitudes toward organ donation: An Australian perspective. Dimens Crit Care Nurs. 1998; 17(5):264-70.

25. Pugliese MR, Degli Esposti D, Venturoli N, Mazzetti Gaito P, Dormi A, Ghirardini A, et al. Hospital attitude survey on organ donation in the EmiliaRomagna region, Italy. Transpl Int. 2001 Dec; 14(6):411-9.

26. Ríos A, López-Navas A, Ayala-García MA, Sebastián MJ, Abdo-Cuza A, Febrero B, et al. Multivariate analysis of the factors affecting attitude toward living liver donation among workers in surgical services in Spanish, Mexican, and Cuban hospitals. Transplant Proc. 2012; 44(6):1482-5.

27. Yuet-mui C, Po-Lin PL, Wai-kuen L, Ngun-ho W. Attitudes of Hong Kong nurses toward cadaveric organ donation. ANNA J. 1997; 24(4):413-9.

28. Alsaied O, Bener A, Al-Mosalamani Y, Nour B. Knowledge and attitudes of health care professionals toward organ donation and transplantation. Saudi J Kidney Dis Transpl. 2012 Nov; 23(6):1304-10.

29. Shabanzadeh AP, Sadr SS, Ghafari A, Nozari BH, Toushih M. Organ and tissue donation knowledge among intensive care unit nurses. Transplant Proc. 2009 Jun; 41(5):1480-2.

30. Kim JR, Fisher MJ, Elliott D. Attitudes of intensive care nurses towards brain death and organ transplantation: Instrument development and testing. J Adv Nurs. 2006 Mar; 53(5):571-82.

31. Siddiqui OT, Nizami S, Raza E, Ali MU, Bikak M, Siddiqui $S$, et al. Deceased-donor organ transplantation: Knowledge and attitudes among health care professionals managing critically ill patients in Karachi. Exp Clin Transplant. 2012 Dec; 10(6):544-50.
32. Smudla A, Mihály S, Okrös I, Hegedűs K, Fazakas J. Attitude and knowledge of intensive care staff concerning donation in Hungary: it is the first step to change. Crit Care. 2013; 17(2):512.

33. Leal-Mateos M, Flores-Rivera E, Rimolo-Donadio F, Matamoros-Ramírez MA, Mora-Badilla G. Conocimientos y actitudes del personal de salud hacia la donación de órganos para trasplante. Rev Costarric Cienc Med. 2005; 26(1-2):15-22.

34. Abbud-Filho M, Miyasaki MCOS, Ramalho HJ, Domingos N, Garcia R, Pucci F. Survey of concepts and attitudes among healthcare professionals toward organ donation and transplantation. Transplant Proc. 1997 Dec; 29(8):3242-3.

35. Omnell-Persson M, Dmitriev P, Shevelev V, Zelvys A, Hermerén G, Persson NH. Attitudes towards organ donation and transplantation. A study involving Baltic physicians. Transpl Int. 1998 Jan; 11(6):419-23.

36. Gorena M, González R, Castillo L. Visión de los profesionales de la salud acerca de la donación y trasplante de órganos en un centro de trasplante renal. Rev Chil Urol. 2003; 68(1):93-8.

37. Rodríguez F, Monteon I. Encuesta de opinión sobre la donación de órganos. Acta Medica Cordoba. 2004; 2(1):7-12.

38. Reddy AVR, Guleria S, Khazanchi RK, Bhardwaj M, Aggarwal S, Mandal S. Attitude of patients, the public, doctors, and nurses toward organ donation. Transplant Proc. 2003 Feb; 35(1):18.

39. Al-Mousawi M, Abdul-Razzak M, Samhan M. Attitude of ICU staff in Kuwait regarding organ donation and brain death. Transplant Proc. 2001 Aug; 33(5):2634-5.

40. Mesa-Lago C. O sistema de saúde brasileiro: seu impacto na pobreza e na desigualdade. Nueva Soc Espec em Port. 2007; 115-31.

41. Lock M, Crowley-Makota M. Situating the practice of organ donation in familial, cultural, and political context. Transplant Rev. 2008 Jul; 22(3):154-7.

42. Manstead ASR. Attitudes and behavior. In: Smelser $\mathrm{N}$, Baltes $\mathrm{P}$, editors. International encyclopedia of the social \& behavioral sciences. Oxford (UK): Elsevie; 2001. p. 909-13.

43. González-Rey F. La categoría actitud en la Psicología. Rev Cuba Psicol. 1987; 4(1):47-59.

44. Kierans C, Padilla-Altamira C, Garcia-Garcia G, Ibarra-Hernandez M, Mercado FJ. When health systems are barriers to health care: challenges faced by uninsured Mexican kidney patients. PLoS One. 2013 Jan; 8(1):e54380.

45. Prottas J, Batten HL. Health professionals and hospital administrators in organ procurement: Attitudes, reservations, and their resolutions. Am J Public Health. 1988 Jun; 78(6):642-5. 
46. Tong A, Winkelmayer WC, Craig JC. Qualitative research in CKD: an overview of methods and applications. Am J Kidney Dis. 2014 Sep; 64(3):338-46.

47. Global Observatory on Donation and Transplantation. Organ donation and transplantation: activities, laws and organization 2010. [s.1]: WHO; 2010.
48. Mercado-Martínez FJ, Díaz-Medina BA, HernándezIbarra E. Achievements and barriers in the organ donation process: a critical analysis of donation coordinators' discourse. Prog Transplant. 2013 Sep; 23(3):258-64. 